\title{
Development of Modification of Big Ball Game with Play Approach in Order to Develop Basic Movement Skills in Elementary School Students
}

\author{
Indah Verawati ${ }^{1}$, Rahma Dewi ${ }^{2}$, Doris Apriani Ritonga ${ }^{3}$ \\ ${ }^{1,2,3}$ Faculty of Sports Science, Universitas Negeri Medan, Indonesia \\ Indahverawati07@gmail.com,rahmadewi368@gmail.com,dorisritoliesefi@unimed.ac.id
}

\begin{abstract}
This study aims to modify the basic motion-based big ball game with a play approach in order to develop basic movement skills and be developed as a guide for sports teachers and learning with game concepts. The resulting product is a CD and a good ball game manual with a playing approach. The research was developed by adapting the Gall, Gall, \& Borg educational research and development model. The development procedure used includes several stages: 1) analyzing the content of the developed product, 2) developing the initial game product, 3) expert validation, 4) field testing, 5) product revision of the data analysis techniques used in this study in two ways, namely quantitative and qualitative.
\end{abstract}

Keywords

modifications; great ball play; basic movement skills

\section{Introduction}

Sport is something that is needed by the body. In addition to being healthy for the body, sports can also train togetherness, make individuals happier or happier and able to foster cohesiveness in a team. Sportsin the form of games such as volleyball,cricket, hockey and soccer are good ways to maintain one's physical fitness and mental health. Many parents, teachers, schools encourage children to engage in some kind of Sports.

Physical Education Sport and health is a subject given at a particular school level which is one part of overall education that prioritizes physical activity and fostering alife healthy for rowth and development of physically, mentally, socially and emotionally that is harmonious, harmonious and balanced (Depdiknas, 2006: 131). In general secondary education units that serve students with special needs, of course, require special handling in providing the learning process (Muchtar, 2020).

Especially for elementary school children need a high creative power in order to be able to create a fun game. Children generally like games that are not heavy but can train their cohesiveness, agility and creativity as well as improve their basic movement skills. The basic movements of walking, running and jumping are basic locomotor movements that need to be developed in elementary school (SD) in addition to other basic movements. Basic locomotor movements are one of the domains of fundamental basic movements, in addition to non-locomotor basic movements and manipulative basic movements, locomotor basic movements which are the subject taught in elementary schools (SD).

Children must be taught how to do good and correct movements, if children are able to do the right movement activities and are carried out continuously, the child will have a strong and healthy body and better movement. Furthermore, Kadek et al (2015: 195) said that children need to be equipped with various basic movement skills that are good according to their abilities and age, this has a positive impact on their physical and psychological growth and development. Another opinion is expressed by Ria (2013: 7) 
with a variety of motion experiences in children, they will have good movement patterns and awareness, so they are able to perform efficient movements in a variety of varied situations.

Based on the expert opinion above, it can be concluded that physical activities carried out in childhood are very important given to improve basic movement abilities. This has a positive impact on children's growth and development in line with the development of other abilities. The 2013 SD/MI curriculum is designed to provide opportunities for students to learn based on their interests. The curriculum structure allows students to make choices in the form of specialization groups, cross-interest options, and/or deepening interest options. One of the Physical Education Materials for the 2013 curriculum for elementary school which contains material for big ball games. The learning material for the big ball game covers various sports, namely football, volleyball, and basketball.

In learning physical education, games in the curriculum structure must be implemented according to the needs of students in elementary schools. Because students can learn through play with joy and channel the desire to move. This is even better if it is equipped with adequate facilities and infrastructure. The more the need for movement is met during its growth period, the greater the impact on the quality of growth itself.

Improving the quality of movement in children should receive attention by teachers of Physical Education, Sports and Recreation (PJOK). It's just that in the implementation of learning big ball games in elementary schools in general, there are problems. This is based on the results of the questionnaire instrument given to physical education teachers in the city of Medan. The findings are 1). The lack of field infrastructure is an obstacle to the implementation of big ball learning. 2). In general, physical education learning in elementary schools, teachers teach children with actual skills by using actual equipment. So that students find it difficult to master the big ball game in the learning process, 3) not all schools have adequate facilities and infrastructure. 4). With limited facilities and infrastructure, Schools require teachers to be able to improve students' skills in every Physical Education learning material. 5) the basic movement learning carried out by the teacher is still seen as limited to the material by explaining it at the beginning of learning using the command method so that students follow more orders / cues from the teacher. 6) The lack of student motivation in participating in learning the big ball game because of the limitations of the ball used. 7). Lack of student movement activity because movement activities are not optimal in developing the cognitive, affective and psychomotor domains. 5) the basic movement learning carried out by the teacher is still seen as limited to the material by explaining it at the beginning of learning using the command method so that students follow more orders / cues from the teacher. 6) The lack of student motivation in participating in learning the big ball game due to the limitations of the ball used. 7). Lack of student movement activity because movement activities are not optimal in developing the cognitive, affective and psychomotor domains. 5) the basic movement learning carried out by the teacher is still seen as limited to the material by explaining it at the beginning of learning using the command method so that students follow more orders / cues from the teacher. 6) The lack of student motivation in participating in learning the big ball game because of the limitations of the ball used. 7). Lack of student movement activity because movement activities are not optimal in developing the cognitive, affective and psychomotor domains.

Based on the background stated above, it is necessary to solve the problem by modifying the basic motion-based big ball game with a playing approach in order to develop basic movement skills. 


\section{Research Methods}

The research subjects in this study were elementary school students. For small group trials consisting of 20 elementary school students. The large group trial consisted of 40 elementary school students. The development method used in this research is the Borg and Gall development model with 7 steps. This was done due to time and cost constraints and this is supported by Sukmadinata (2015) who stated that development research can be stopped until a final draft is produced, without testing the results. The results or impacts of the implementation of the development of movement activities already exist in small group trials and large group trials. The 7 steps are explained as follows: 1) Conducting preliminary research (pre-survey), 2) planning, 3) product drafting, 4) initial testing, 5) revising the product, 6) Conducting field trials, 7) Conducting product revision.

\section{Results and Discussion}

The results of this development research is a modification of the big ball game with a basic motion-based playing approach with a playing approach in order to develop basic movement skills. Where the modified values of the game with this big ball contain important aspects for the development of movement and cognitive development of children.

Based on observations made in several elementary schools, mastery of basic movement skills has not been taught optimally by teachers. Because learning tends to lead to mastery of adult movement skills. The assumption that children are miniature adults causes teachers to teach skills that lead to the mastery of high-level skills.

The main goal of PJOK learning is how to make children move, be happy and participate actively. Children should be taught to do good and correct movements, if children are able to do the right movement activities and are carried out continuously then the child will have a strong and healthy body and better movement.

\subsection{Needs Analysis}

The results of the needs analysis of the importance of developing a game modification with a big ball with a play approach in order to develop basic movement skills in elementary school students for needs analysis from teachers showed that $90 \%$ said they needed it, 5\% answered needed and 5\% said it was not needed. Furthermore, the results of the needs analysis of the group of students showed that $80 \%$ said they needed it very much, $15 \%$ answered it was needed and 5\% said it was not needed. This can be seen in the following table below:

Table 1. Analysis of the needs of the teacher group for modification of the big ball game

\begin{tabular}{|l|r|r|}
\hline & Teacher & Percentage \\
\hline Urgently require & 20 & 80 \\
\hline Need & 4 & 16 \\
\hline Less Need & 0 & 0 \\
\hline No Need & 1 & 4 \\
\hline Amount & $\mathbf{2 5}$ & $\mathbf{1 0 0}$ \\
\hline
\end{tabular}


Table 2. Analysis of the needs of the student group for modification of the big ball game

\begin{tabular}{|l|r|r|}
\hline & Student & Percentage \\
\hline Urgently require & 60 & 80 \\
\hline Need & 10 & 13.33 \\
\hline Less Need & 0 & 0 \\
\hline No Need & 5 & 6.67 \\
\hline amount & 75 & 100 \\
\hline
\end{tabular}

\subsection{Product Validation}

After the modification of the big ball game product with a play approach was made, the next step was to test the physical education learning expert. In this case, his opinion was asked on the modified product of the big ball game for elementary school students in order to develop basic movement skills. This expert validation aims to provide an assessment and input on the modified product of the big ball game with a play approach so that it meets the criteria that are theoretically and empirically feasible to be applied. in elementary school children. This is done so that the resulting product can be better and suitable for use.

The product that has been made is then shown to the physical education expert to assess how the product is developed. This test is given to 3 physical education experts to provide corrections and input and obtain assessment data for the modification of the big ball game with a play approach whether it is feasible or not to be tested. on a small or large scale. The following are suggestions from the three experts for a big ball game modification product with a playing approach.

Table 3. Product Revisions from Experts

\begin{tabular}{|c|c|c|c|c|c|c|}
\hline \multirow[t]{2}{*}{ No. POST } & \multicolumn{2}{|c|}{ Expert 1} & \multicolumn{2}{|c|}{ Expert 2} & \multicolumn{2}{|c|}{ Expert 3} \\
\hline & $\begin{array}{c}\text { Reason for } \\
\text { Revision }\end{array}$ & $\begin{array}{c}\text { Repair } \\
\text { Suggestions }\end{array}$ & $\begin{array}{c}\text { Reason for } \\
\text { Revision }\end{array}$ & $\begin{array}{c}\text { Repair } \\
\text { Suggestions }\end{array}$ & $\begin{array}{l}\text { Reason for } \\
\text { Revision }\end{array}$ & $\begin{array}{l}\text { Repair } \\
\text { Suggestions }\end{array}$ \\
\hline $\begin{array}{l}\text { Game Mod } \\
1\end{array}$ & $\begin{array}{l}\text { The } \\
\text { distance is } \\
\text { too close }\end{array}$ & $\begin{array}{l}\text { Better } \\
\text { distance } 3 \mathrm{~m}\end{array}$ & $\begin{array}{l}\text { Distance is } \\
\text { too short }\end{array}$ & Better 3m & $\begin{array}{l}\text { The } \\
\text { jump } \\
\text { box is } \\
\text { raised } \\
\text { so that } \\
\text { the } \\
\text { child } \\
\text { does not } \\
\text { lose his } \\
\text { balance }\end{array}$ & $\begin{array}{l}\text { The box is } \\
\text { raised to a } \\
\text { size of } 50 \\
\mathrm{~cm} \times 50 \\
\mathrm{~cm}\end{array}$ \\
\hline $\begin{array}{l}\text { Game Mod } \\
2\end{array}$ & $\begin{array}{l}\text { The game } \\
\text { boxes are } \\
\text { made in } \\
\text { color to } \\
\text { make it } \\
\text { more } \\
\text { interesting }\end{array}$ & $\begin{array}{l}\text { Use colorful } \\
\text { chalk }\end{array}$ & $\begin{array}{l}\text { The ball is } \\
\text { too small }\end{array}$ & $\begin{array}{l}\text { Doper ball as } \\
\text { big as a } \\
\text { coconut }\end{array}$ & $\begin{array}{l}\text { Colored } \\
\text { ball }\end{array}$ & $\begin{array}{l}\text { Colorful } \\
\text { balls to } \\
\text { make it } \\
\text { more } \\
\text { interesting }\end{array}$ \\
\hline $\begin{array}{l}\text { Game Mod } \\
3\end{array}$ & $\begin{array}{l}\text { The distance } \\
\text { is too far, } \\
\text { making it } \\
\text { difficult for } \\
\text { children to } \\
\text { move }\end{array}$ & $\begin{array}{l}\text { Distance } \\
3 \mathrm{~m}\end{array}$ & $\begin{array}{l}\text { The distance } \\
\text { is too far }\end{array}$ & Distance $3 \mathrm{~m}$ & $\begin{array}{l}\text { The } \\
\text { distance } \\
\text { is too } \\
\text { far }\end{array}$ & $\begin{array}{l}\text { Distance } \\
2 \mathrm{~m}\end{array}$ \\
\hline
\end{tabular}




\begin{tabular}{|l|l|l|l|l|l|l|}
\hline $\begin{array}{l}\text { Game mods } \\
4\end{array}$ & $\begin{array}{l}\text { Target } \\
\text { target is } \\
\text { too small } \\
\text { zoomed in }\end{array}$ & $\begin{array}{l}\text { Target } \\
\text { distance is } \\
\text { too far }\end{array}$ & $\begin{array}{l}\text { Distance } \\
\text { made 2 } \mathrm{m}\end{array}$ & $\begin{array}{l}\text { Students } \\
\text { are } \\
\text { divided } \\
\text { into two } \\
\text { groups }\end{array}$ & $\begin{array}{l}\text { So that } \\
\text { students } \\
\text { don't wait } \\
\text { too long } \\
\text { for their } \\
\text { turn }\end{array}$ \\
\hline $\begin{array}{l}\text { Game } \\
\text { modification } \\
5\end{array}$ & $\begin{array}{l}\text { Target } \\
\text { made in } \\
\text { color }\end{array}$ & $\begin{array}{l}\text { Target will } \\
\text { be } \\
\text { interesting }\end{array}$ & $\begin{array}{l}\text { ball more } \\
\text { than 1 }\end{array}$ & $\begin{array}{l}\text { There are 4 } \\
\text { balls } \\
\text { provided }\end{array}$ & $\begin{array}{l}\text { The } \\
\text { jump is } \\
\text { not too } \\
\text { high }\end{array}$ & $\begin{array}{l}\text { The jump } \\
\text { is made as } \\
\text { high as 20 } \\
\text { cm }\end{array}$ \\
\hline $\begin{array}{l}\text { Game } \\
\text { modification } \\
6\end{array}$ & $\begin{array}{l}\text { In } \\
\text { accordance } \\
\text { with basic } \\
\text { movement } \\
\text { skills }\end{array}$ & $\begin{array}{l}\text { Basic } \\
\text { moves, run, } \\
\text { jump and } \\
\text { sheet }\end{array}$ & $\begin{array}{l}\text { Too many } \\
\text { modifications }\end{array}$ & $\begin{array}{l}\text { Made 4 } \\
\text { variations of } \\
\text { modifications }\end{array}$ & $\begin{array}{l}\text { Modify } \\
\text { from } \\
\text { easy to } \\
\text { difficult }\end{array}$ & $\begin{array}{l}\text { Using } \\
\text { basic } \\
\text { motion } \\
\text { principles }\end{array}$ \\
\hline
\end{tabular}

\subsection{Small Group Trial}

Product development results big ball game modification with play approach sehe continued, it was tested in small groups to see the effectiveness of existing products. Trialsproduct The modification of the big ball game with a play approach was carried out by 10 students from SDS Gajahmada. In the implementation of this small group trial, 10 students looked enthusiastic and enthusiastic in playing. Each student was curious and eager to try.

After 10 students of SDS Gajahmada Medan made modifications to the big ball game with a play approach, then the students were assessed based on the instrument's ability to assess students. To determine the effectiveness of the product can be seen the results of trials in small groups below:

Table 4. Small Group Trial Results

\begin{tabular}{|c|c|c|}
\hline Respondents & Amount & $\mathbf{P}(\%)$ \\
\hline 1 & 65 & 81.25 \\
\hline 2 & 67 & 83.75 \\
\hline 3 & 55 & 68.75 \\
\hline 4 & 66 & 82.50 \\
\hline 5 & 70 & 87.50 \\
\hline 6 & 61 & 76.25 \\
\hline 7 & 64 & 80.00 \\
\hline 8 & 58 & 72.50 \\
\hline 9 & 64 & 80.00 \\
\hline 10 & 64 & 80.00 \\
\hline Amount & 634 & \\
\hline \multicolumn{3}{|c|}{ AVERAGE $=72.04 \%$} \\
\hline
\end{tabular}

From the value obtained, it is known that the empirical score obtained is $72.04 \%$ (Appropriate to Use) so it can be stated that the game product can be used.

\subsection{Large Group Trial}

The results of the development of the modification of the big ball game with the play approach were then tested in large groups to see the effectiveness of the existing products. The trial of the modified big ball game product with a play approach was carried out by 40 
students from SDS Islam Al Ulum Terpadu, SDS Gajahmada, SDN No: 1017774, SDN No: 101775, SDN No: 101776 Medan City. The modified game of a big ball game with a playing approach that was carried out in a large group trial showed good student enthusiasm because students before being tested had been given several explanations. Next, see the results of the following assessment:

Table 5. Percentage (\%) Large Group Trial

\begin{tabular}{|c|r|r|r|r|r|}
\hline Respondents & amount & $\mathbf{P}(\mathbf{\%})$ & Respondents & amount & \multicolumn{1}{|}{ ( \%) } \\
\hline $\mathbf{1}$ & 75 & 93.75 & $\mathbf{2 1}$ & 74 & 92.5 \\
\hline $\mathbf{2}$ & 71 & 88.75 & $\mathbf{2 2}$ & 72 & 90 \\
\hline $\mathbf{3}$ & 73 & 91.25 & $\mathbf{2 3}$ & 75 & 93.75 \\
\hline $\mathbf{4}$ & 76 & 95 & $\mathbf{2 4}$ & 77 & 96.25 \\
\hline $\mathbf{5}$ & 71 & 88.75 & $\mathbf{2 5}$ & 71 & 88.75 \\
\hline $\mathbf{6}$ & 72 & 90 & $\mathbf{2 6}$ & 75 & 93.75 \\
\hline $\mathbf{7}$ & 73 & 91.25 & $\mathbf{2 7}$ & 75 & 93.75 \\
\hline $\mathbf{8}$ & 76 & 95 & $\mathbf{2 8}$ & 76 & 95 \\
\hline $\mathbf{9}$ & 75 & 93.75 & $\mathbf{2 9}$ & 73 & 91.25 \\
\hline $\mathbf{1 0}$ & 71 & 88.75 & $\mathbf{3 0}$ & 74 & 92.5 \\
\hline $\mathbf{1 1}$ & 74 & 92.5 & $\mathbf{3 1}$ & 74 & 92.5 \\
\hline $\mathbf{1 2}$ & 68 & 85 & $\mathbf{3 2}$ & 70 & 87.5 \\
\hline $\mathbf{1 3}$ & 76 & 95 & $\mathbf{3 3}$ & 77 & 96.25 \\
\hline $\mathbf{1 4}$ & 74 & 92.5 & $\mathbf{3 4}$ & 75 & 93.75 \\
\hline $\mathbf{1 5}$ & 76 & 95 & $\mathbf{3 5}$ & 77 & 96.25 \\
\hline $\mathbf{1 6}$ & 75 & 93.75 & $\mathbf{3 6}$ & 76 & 95 \\
\hline $\mathbf{1 7}$ & 77 & 96.25 & $\mathbf{3 7}$ & 78 & 97.5 \\
\hline $\mathbf{1 8}$ & 72 & 90 & $\mathbf{3 8}$ & 75 & 93.75 \\
\hline $\mathbf{1 9}$ & 79 & 98.75 & $\mathbf{3 9}$ & 79 & 98.75 \\
\hline $\mathbf{2 0}$ & 75 & 93.75 & $\mathbf{4 0}$ & 76 & 95 \\
\hline $\mathbf{a m o u n t}$ & $\mathbf{1 4 7 9}$ & & $\mathbf{a m o u n t}$ & $\mathbf{1 4 9 9}$ & \\
\hline
\end{tabular}

From the value obtained, it is known that the empirical score obtained is 93.06 (Very Appropriate to Use). This means that this research is sufficient to determine the validity of the modified game of a big ball game with a play approach to basic movement abilities in elementary school students in Medan.

\section{Conclusion}

The development of a modified big ball game with a play approach to basic movement skills in elementary school students based on a play approach is expected to assist teachers in teaching basic movement skills to elementary school students.

Furthermore, improving students' basic movement skills can develop optimally in accordance with the competency standards that have been set for elementary school students. With a play approach, elementary school students will carry out activities happily. This is because the games that are played will make students happy by actively moving. 


\section{References}

Ahmad Komaruzaman. (2018). Pembelajaran Gerak Dasar Dalam pembelajaran pendidikan Jasmani, Olahraga Dan Kesehatan di Sekolah Dasar melalui Permainan. Prosiding Seminar dan Diskusi nasional pendidikan Dasar. ISSN: 2528-5564. Hal 254-258.

Beth P. Hands. (2012). How fundamental are fundamental movement skills. Health Sciences Papers and Journal Articles. Vol. 19 No. 1. P 11-13.

Firmansyah, H. (2009). Hubungan Motivasi Berprestasi Siswa dengan Hasil Belajar Pendidikan Jasmani. Jurnal Pendidikan Jasmani Indonesia Volume 6 No. 1.

Hendrayana, Yudi. (2003). Pembelajaran Permainan Dasar. Bandung: FPOK UPI.

Koko Prasetyo. (2016). Penerapan Pendekatan Bermain Untuk Meningkatkan Hasil Belajar Lompat jauh gaya Jongkok pada Siswa kelas 5 Sekolah Dasar. Jurnal Scholaria, Vol 6, hal:196-2015.

Kadek Ari Wibawa,FX Sugiayanto.(2015). Gerak Multilateral Melalui Permainan Bola Besar untuk Anak SD Kelas Bawah. Jurnal Keolahragaan.Vol.2 No 2 : hal 194-207.

Lesmana Nugraha, Agus Mahendra, Indra Herdiyana. (2018). Penerapan Model Pendidikan Gerak Dalam Pengembangan Pola Gerak Dasar Manipulatif Melalui Kerangka Analisis gerak (Movement Analysis Framework).

Maidar. (2017). Model pendekatan bermain dalam upaya meningkatkan kebugaran jasmani Siswa Tunarungu. Jurnal Ilmu Pendidikan Sosial, sains, dan Humaniora Vol. 3 No. 4, 829-842.

Martin. (2016). Pengembangan Model perimaian Basketball and Football Combination Untuk pembelajaran PENJASORKES Siswa Sekolah Dasar. Journal Of Physival Education, Helath and Sport.ISSN2354-8231 (online).ISSN 2354-7901(Cetak).h:7-14.

Mohammad Fauziddin. (2017). Penerapan Belajar Melalui Bermain Balok Dalam Meningkatkan Motorik Halus Anak Usia Dini. Jurnal CARE Vol. 5 (1). ISSN (print): 2355-2034 / ISSN (online): 2527-9513.1-10.

Muchtar, I., Kartiko, D.C., and Tuasikal, A.R. (2020). Development of a Long Jump Education Model through a Game Approach to Improve Basic Movement for Students with Disabilities Grahita in Inclusive Schools at SMP Negeri 28 Surabaya. Budapest International Research and Critics in Linguistics and Education (BirLE) Journal Vol 3 (3): 1479-1488.

Paeran Baderun. (2014). Meningkatkan Kemampuan Teknik Dasar Permainan Bola Besar Melalui Metode Praktek Berpasangan. Jurnal Pendidikan Jasmani Olahraga dan Kesehatan. Jilid 2.No 1. H: 77-86.

Permendikbud tahun 2016 Nomor 24

Ria Lumintuarso. (2013). Pembinaan Multilateral Bagi Atlet Pemula.Yogyakarta:UNY press.

Ricky Wibowo, Eka Nugraha, Kuston Sultoni. 2018. Fundamental Movement Skill and Moods as Predictors of Games Performance in Primary School Students. Journal of Physical Education, Sport, Health and Recreations vol 7 (1) 44-49.

Silvia Martha Agustin, Heryanto Nur Muhammad. (2015). Pengaruh aktifitas gerak pemainan tradisional terhadap kelincahan siswa. Jurnal Pendidikan Olahraga dan Kesehatan Volume 03 Nomor 02 Tahun 2015, 549 - 553.

Yani Nurdiani. (2013). Penerapan prinsip bermain sambil belajar dalam mengembangkan multiple inteligencia pada pendidikan anak usia dini. Jurnal EMPOWERMENT Volume 2, Nomor 2 September 2013, ISSN No. 2252-4738.

Witono Hidayat. (2017).Buku Pintar Bola Voli. Jakarta.Anugerah. 